\title{
Glaucoma in a case of Hurler disease
}

\author{
ELIZABETH SPELLACY, ${ }^{1}$ J. L. KENNERLEY BANKES, ${ }^{2}$ JULIE CROW, ${ }^{3}$ \\ R. DOURMASHKIN, ${ }^{4}$ D. SHAH, ${ }^{4}$ AND R. W. E. WATTS \\ From the ${ }^{1}$ Division of Inherited Metabolic Diseases and ${ }^{4}$ Electron Microscopy Section, \\ MRC Clinical Research Centre, ${ }^{3}$ Department of Histopathology, Northwick Park Hospital, \\ and the ${ }^{2}$ Western Ophthalmic Hospital, London WI
}

SUMMARY The electron microscopic appearances of the corneoscleral and iris tissue removed at operation from a child with Hurler disease and glaucoma showed distinctive swollen cells with intracellular inclusions similar to those which are observed in other tissues in these patients and which are due to abnormal lysosomal storage of mucopolysaccharides. Some recent observations on the possible relationship between mucopolysaccharides and the drainage of fluid from the anterior chamber are briefly reviewed and correlated with the present observations. The development of glaucoma in this patient is thought to be associated with the presence of the mucopolysaccharidecontaining cells in the region of the aqueous drainage channels.

The mucopolysaccharidoses are a subgroup of the lysosomal storage diseases as defined by Hers ${ }^{1}$ in which the inherited deficiency of a specific exoglycosidase prevents the normal lysosomal degradation of the glycosaminoglycans (mucopolysaccharides), which therefore accumulate in lysosomes and produce characteristic morphological changes. The urine also contains excessive amounts of glycosaminoglycans. Table 1 lists the mucopolysaccharidoses with their specific enzyme deficiencies, excreted glycosaminoglycans, pattern of inheritance, and the tissue systems which are mainly affected in the individual disorders. Leroy and Neetens ${ }^{2}$ mention a clinical association between these diseases and glaucoma, though the glaucoma may be obscured by corneal clouding. The corneal clouding is well recognised in Hurler and Scheie diseases, the Hurler/Scheie intermediate phenotype, as well as in Morquio and Maroteaux-Lamy diseases. The youngest patients with Hurler disease whom we have encountered have been between 6 and 9 months old, and they have all had corneal clouding at this stage of the disease, when the other clinical signs are slight and the evidence for developmental delay may be quite slender. The corneae characteristically remain clear in Hunter disease, though an enzymologically proved case with this complication was recently reported. ${ }^{3}$

This paper reports the development of open-angle

Correspondence to Dr R. W. E. Watts, Division of Inherited Metabolic Diseases, Clinical Research Centre, Watford Road, Harrow, Middlesex HAl 3UJ. glaucoma in a child with Hurler disease and describes the electron microscopic appearances in tissue from the corneoscleral junction and iris.

\section{Materials and methods}

\section{CASE REPORT}

The patient was a 6-year-old girl with all the classical clinical features of Hurler disease. Her facial features are shown in Fig. 1. She excreted excessive amounts of dermatan and heparan sulphates in her urine. The diagnosis was established biochemically by the absence of $\alpha$-L-iduronidase activity from her white blood cells and cultured skin fibroblasts. Differentiation from Hunter disease was also confirmed by showing the excessive uptake and retention of ${ }^{35} \mathrm{SO}_{4}$ by her fibroblasts in vitro, which was corrected by subculturing the cells in tissue culture medium in which a Hunter disease patient's fibroblasts had previously grown. ${ }^{4}$

She was receiving regular ophthalmic examinations at 6-monthly intervals as an outpatient when it was suspected that the ocular tensions were raised. Ophthalmic examinations showed moderate bilateral corneal clouding, corneal diameters of $11.5 \mathrm{~mm}$ (horizontally) and $11.5 \mathrm{~mm}$ (vertically) in both eyes, clear crystalline lenses, and normal fundi, but early glaucomatous cupping and pallor of the discs. Shortly afterwards, while awaiting ophthalmic examination under anaesthetic, she developed an acute left orbital cellulitis, which was associated with rapid loss of vision down to perception of hand movements only. The orbital cellulitis subsided 
Table 1 The mucopolysaccharidoses

\begin{tabular}{|c|c|c|c|c|c|}
\hline $\begin{array}{l}\text { McKusick's } \\
\text { classification" }\end{array}$ & $\begin{array}{l}\text { Eponymous } \\
\text { name }\end{array}$ & Enzyme deficiency & $\begin{array}{l}\text { Excreted } \\
\text { glycosaminoglycans }\end{array}$ & Inheritance & $\begin{array}{l}\text { Organs mainly } \\
\text { affected }\end{array}$ \\
\hline $\mathbf{I H}+$ & Hurler & $\alpha$-L-Iduronidase & $\begin{array}{l}\text { Dermatan sulphate } \\
\text { Heparan sulphate }\end{array}$ & Autosomal recessive & $\begin{array}{l}\text { Central nervous system } \\
\text { Skeleton } \\
\text { Viscera }\end{array}$ \\
\hline IS & Scheie & $\alpha$-L-Iduronidase & $\begin{array}{l}\text { Dermatan sulphate } \\
\text { Heparan sulphate }\end{array}$ & Autosomal recessive & $\begin{array}{l}\text { Skeleton (mild relative to } \\
\text { Hurler) } \\
\text { Viscera (mild relative to } \\
\text { Hurler) }\end{array}$ \\
\hline IH/S & Hurler/Scheie & $\alpha$-L-Iduronidase & $\begin{array}{l}\text { Dermatan sulphate } \\
\text { Heparan sulphate }\end{array}$ & Autosomal recessive & $\begin{array}{l}\text { Phenotype intermediate } \\
\text { between Hurler and } \\
\text { Scheie diseases }\end{array}$ \\
\hline II $\dagger$ & Hunter & $\begin{array}{l}\text { Iduronate sulphate } \\
\text { sulphatase }\end{array}$ & $\begin{array}{l}\text { Dermatan sulphate } \\
\text { Heparan sulphate }\end{array}$ & Sex-linked recessive & $\begin{array}{l}\text { Central nervous system } \\
\text { Skeleton } \\
\text { Viscera } \\
\text { Mild and severe pheno- } \\
\quad \text { types reported }\end{array}$ \\
\hline IIIA & Sanfilippo A & Heparan N-sulphatase & Heparan sulphate & Autosomal recessive & Central nervous system \\
\hline IIIB & Sanfilippo B & $\mathrm{N}$-acetyl- $\alpha$-D-glucosaminidase & Heparan sulphate & Autosomal recessive & Central nervous system \\
\hline IV & Morquio & Hexosamine 6-sulphatase & Keratan sulphate & Autosomal recessive & Skeleton \\
\hline $\mathbf{V} \ddagger$ & - & - & - & - & - \\
\hline VI & Maroteaux-Lamy & $\begin{array}{l}\text { N-acetylgalactosamine } \\
\text { 4-sulphatase (aryl } \\
\text { sulphatase B) }\end{array}$ & Dermatan sulphate & Autosomal recessive & $\begin{array}{l}\text { Skeleton } \\
\text { Mild and severe pheno- } \\
\text { types reported }\end{array}$ \\
\hline VII & $\begin{array}{l}\beta \text {-Glucuronidase } \\
\text { deficiency }\end{array}$ & $\beta$-Glucuronidase & $\begin{array}{l}\text { Dermatan sulphate } \\
\text { Heparan sulphate }\end{array}$ & Autosomal recessive & $\begin{array}{l}\text { Central nervous system } \\
\text { Skeleton } \\
\text { Viscera }\end{array}$ \\
\hline
\end{tabular}

*McKusick et al..$^{18}$ originally proposed a numerical classification of types $\mathrm{I}-\mathrm{V}$, and this was subsequently extended.

†Both formerly called gargoylism because of the characteristic and similar facies, which is also seen in the mucolipidoses (a group of 3 biochemically different inherited metabolic diseases) and in some cases of $\alpha$-fucosidosis and mannosidosis. ${ }^{10}$

tOriginally Scheie disease, which was reclassified as mucopolysaccharidosis IS when the enzyme defect was shown to be the same as that in Hurler disease. The possibility that Hurler and Scheie diseases are due to allelic mutations and that the intermediate Hurler/Scheie phenotype (mucopolysaccharidosis IH/S) is due to double heterozygosity for the allelic mutations concerned has been widely proposed. The Hurler/ Scheie phenotype could also be due to homozygosity for a third allelic mutation at the same gene locus.

promptly with antibiotic treatment but without recovery of vision. Subsequent examination under anaesthetic showed ocular tensions of: right eye $42 \mathrm{mmHg}$ and left eye $38 \mathrm{mmHg}$. A clear view of the angles of the anterior chamber was not obtained because of the corneal clouding, except to note that the angles were open without any grossly abnormal features.

In view of the presence of the glaucoma, which had developed rapidly, right and left glaucoma filtering (trabeculectomy) operations were performed. The portions of tissue from the corneoscleral junction and iris removed at operation form the basis of this electron microscopic study. There was little recovery of vision after the operation.

\section{ELECTRON MICROSCOPIC METHODS}

The operation specimens were prepared for electron microscopy by fixation in 3\% glutaraldehyde diluted in $0.1 \mathrm{M}$ cacodylate buffer with $5 \%$ sucrose $(\mathrm{pH}$ 7.4) for 2 hours at room temperature followed by $1 \%$ osmium tetroxide in $0.1 \mathrm{M}$ cacodylate buffer with $5 \%$ sucrose at $4{ }^{\circ} \mathrm{C}$. They were dehydrated in acetone and embedded in Spurr embedding medium. ${ }^{5}$

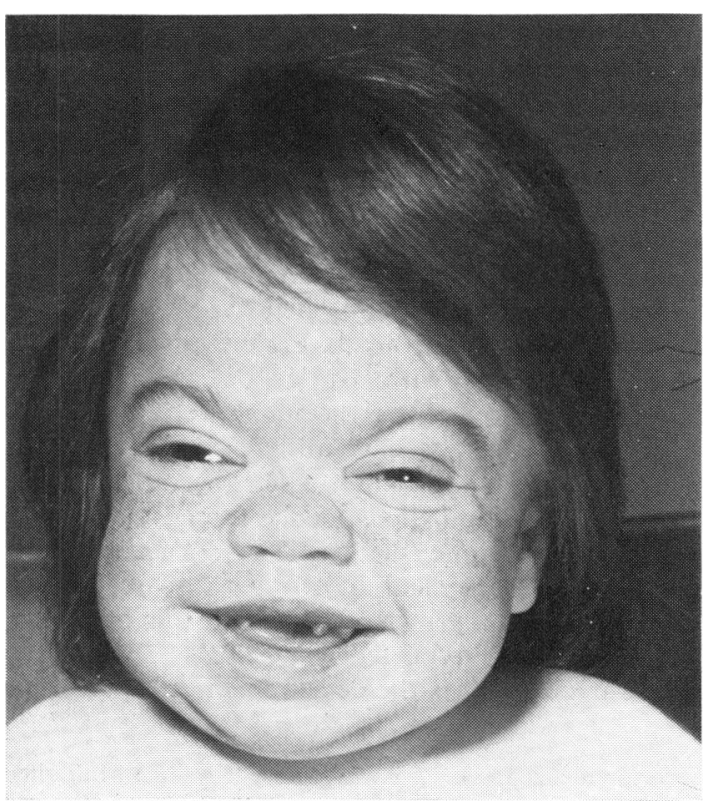

Fig. 1 The patient. 
Sections $1 \mu \mathrm{m}$ thick were prepared, stained with toluidine blue, and examined. Ultrathin sections were then cut with a diamond knife on a Sorvell Porter-Blum II microtome, mounted on copper grids, and stained with saturated uranyl acetate in $50 \%$ alcohol for 10 minutes and with lead citrate for 3 minutes. They were stabilised with a light coat of carbon and examined in a Phillips EM 300 electron microscope. Some control iris tissue from a case of open-angle glaucoma, which was not associated with Hurler disease, was similarly processed for electron microscopic examination.

\section{Results}

\section{CORNEOSCLERAL JUNCTION}

The tissue from the corneoscleral junction consisted of dense bundles of collagen fibres with cells (presumed to be fibroblasts) lying between the bundles. The $1 \mathrm{em}$ toluidine blue sections showed these cells to have considerably swollen and foamy cytoplasm (Fig. 2). The ultrathin sections from these areas showed that the cytoplasm of nearly every cell contained numerous membrane-bound vesicles which either appeared completely clear or contained faint floccular staining and occasional membranes (Fig. 3).

\section{IRIS}

Similar membrane-bound inclusions were found in the cells in the sections from the iris. The highly pigmented cells with numerous melanosomes in general did not show these inclusions, but they were very prominent in the underlying stromal cells (Fig. 4). Similar inclusions were not seen in the corresponding cells in the control iris tissue (Fig. 5).

\section{CONJUNCTIVA AND TENON'S CAPSULE}

Similar cellular inclusions were found in the cells lying between the collagen bundles in this tissue.

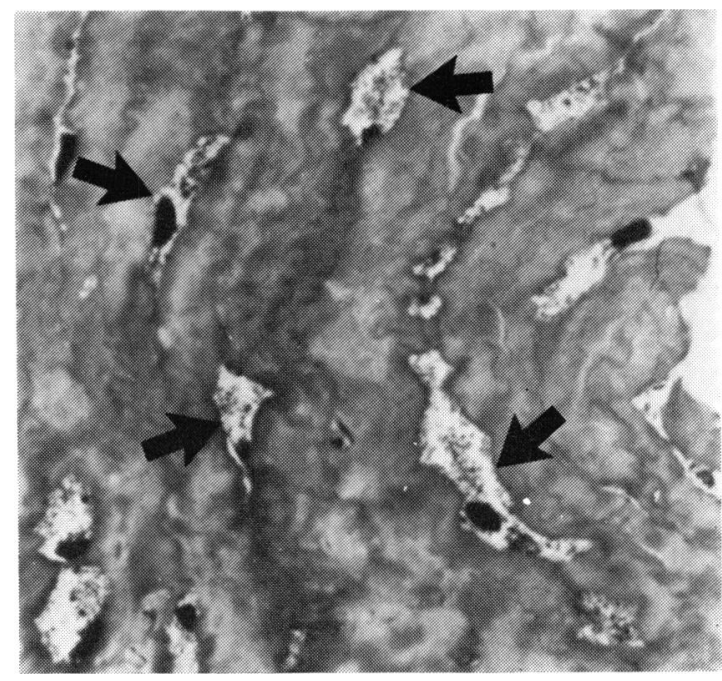

Fig. $21 \mu \mathrm{m}$ thick section of tissue from the area of the canal of Schlemm. Cells with greatly swollen cytoplasm lying between bundles of collagen fibres (arrows). (Toluidine blue $\times 640$ ).

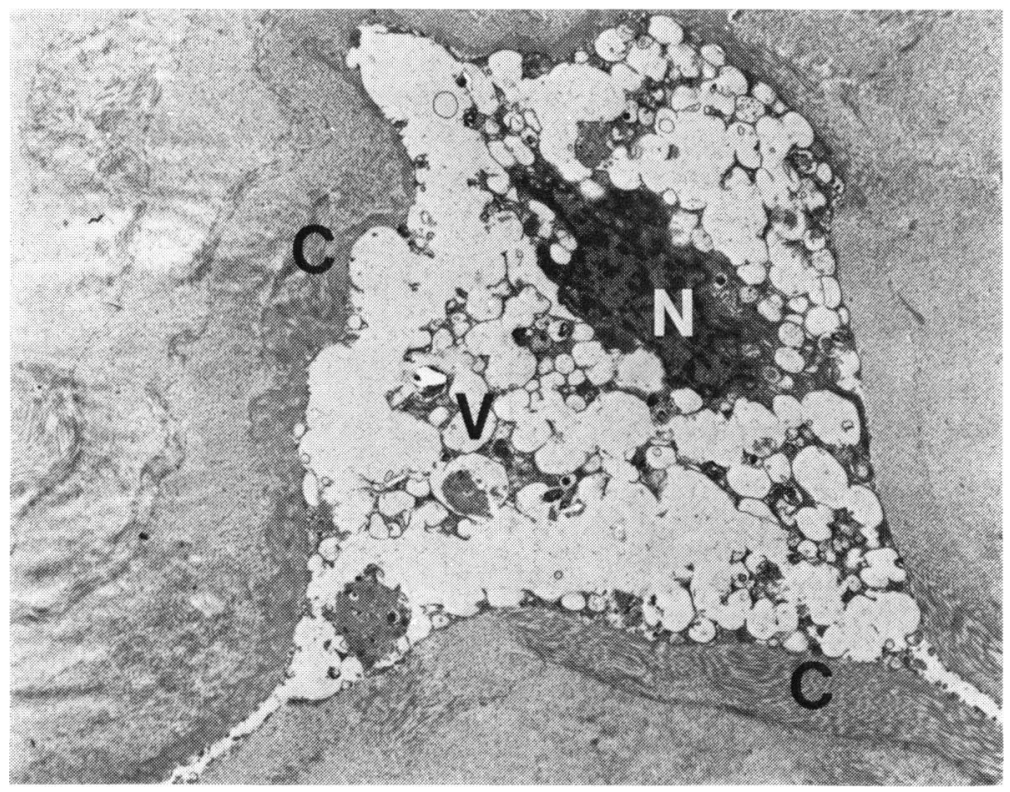

Fig. 3 Electron micrograph of tissue from the area of the canal of Schlemm. The cell cytoplasm is greatly distended by membrane-bound vesicles some of which have coalesced and contain faintly staining material and occasional membranes. $N=$ nucleus. $V=$ vesicles. $C=$ collagen.$(\times 3840)$. 
Fig. 4 Electron micrograph of tissue from the iris. The cytoplasm of many of the cells contains numerous membranebound vesicles with faintlystaining contents. $N=$ nucleus. $V=$ vesicles. $P=$ cells with pigment granules. $(\times 3560)$.

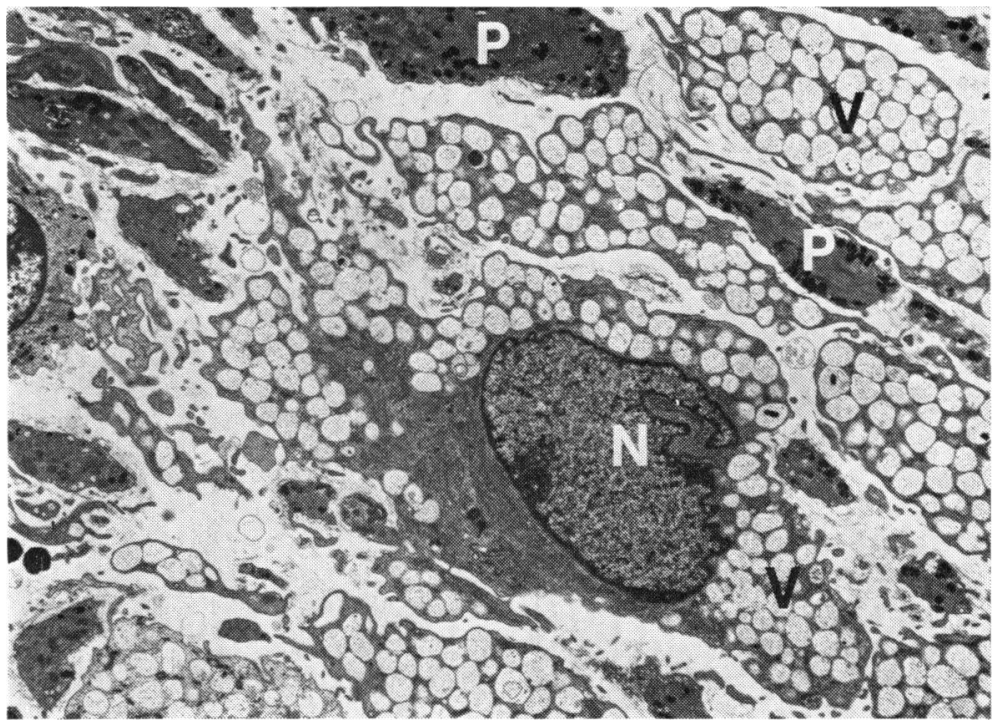

\section{Discussion}

Corneal clouding, retinal pigmentary degeneration, and optic atrophy may all arise as complications of Hurler disease, ${ }^{6}$ and corneal clouding is a consistent, very early sign of the disease. The optic atrophy is of multifactorial origin and may be associated with the retinal pigmentary degeneration, damage to the ganglion cells, mucopolysaccharide deposition within the optic nerve, papilloedema due to hydrocephalus, and glaucoma. The present patient remained blind after the technically success- ful trabeculestomy operations, which indicated direct damage to the visual pathway by either abnormal mucopolysaccharide deposits or complicating vascular occlusion. She was subsequently shown to have progressive internal hydrocephalus with raised intraventricular pressures.

The electron microscopic appearances of the cells in the corneoscleral junction, the iris, and conjunctiva from this patient are similar to those described in other tissues in the disease ${ }^{7}$ and observed by us in the sebaceous glands of skin biopsy from this patient (Fig. 6). Quigley et al. ${ }^{8}$ reported 2 sibs
Fig. 5 Electron micrograph of control iris. Cell containing a few small pigment granules but no large membrane-bound vesicles. $N=$ nucleus.

$P=$ pigment granules. $(\times 8290)$.

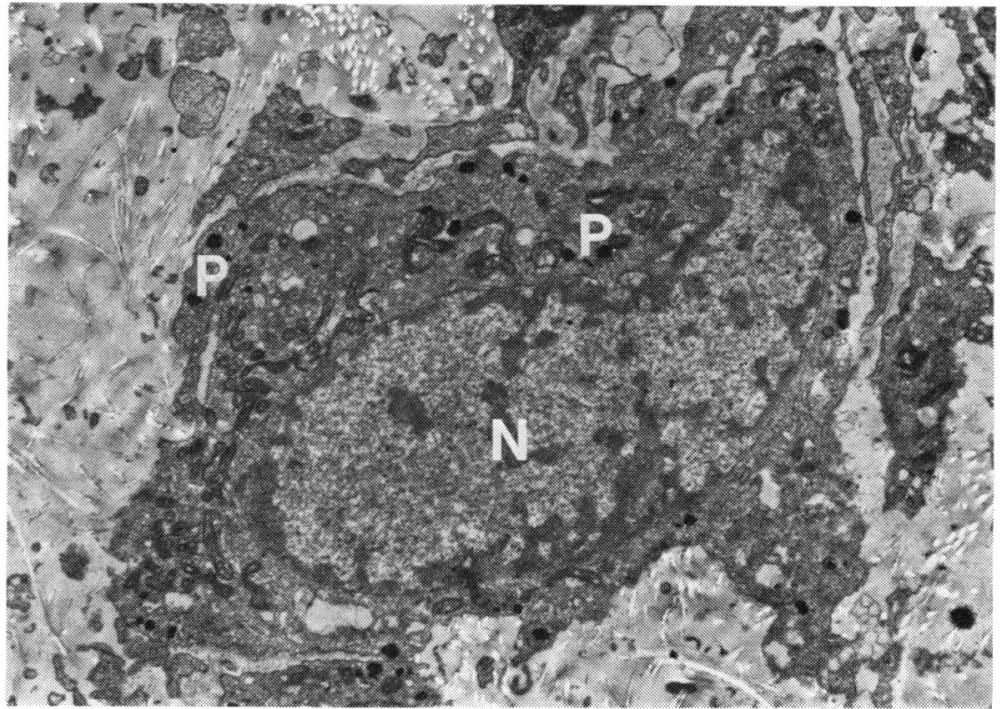




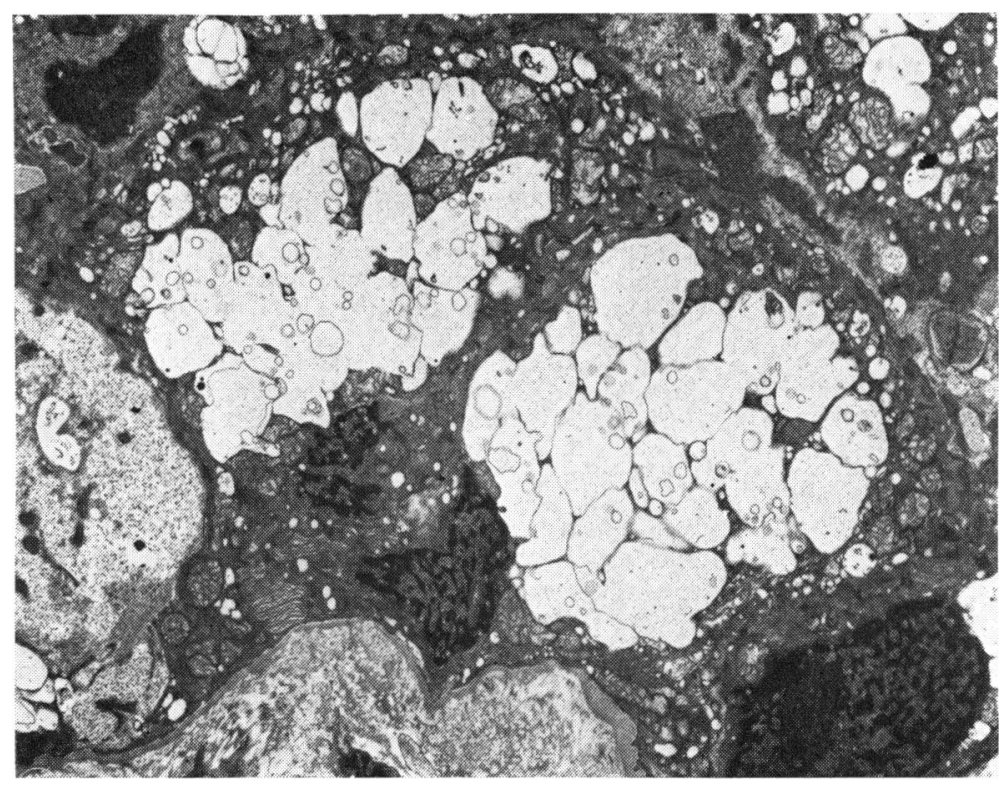

Fig. 6 Electron micrograph of cells in the patient's dermis showing similar membrane-bound inclusions to those seen in the eye. $(\times 4945)$.

with biochemically proved Sche:e disease (mucopolysaccharidosis IS) who developed acute glaucoma. Like ourselves, these workers could not identify any trabecular meshwork in the tissue which was removed surgically, though Descemet's membrane was seen in one specimen. Histochemical staining (colloidal iron and Alcian blue) showed extracellular acidic mucopolysaccharide deposits which were resistant to hyaluronidase.

D'Epinay and Remé ${ }^{9}$ descrited a patient with glaucoma and clinical features resembling either one of the gargoyl-like mucopolysaccharidoses (types IH, II, VII; Table 1), one of the mucolipidoses (types I, II, and $\mathrm{III}^{10}$ ), or some cases of mannosidosis and fucosidosis. ${ }^{10}$ These workers $^{9}$ examined tissue from their patient by electron microscopy and reported intracellular storage vacuoles in the cells lining the drainage canal as well as extracellularly. They also described rupture of the endothelial lining of the canal. Unfortunately their case report lacks any diagnostic biochemical data. Glaucoma is known to occur in Scheie disease, mucopolysaccharidosis IS ${ }^{11}$ (Table 1), and in the Hurler/Scheie intermediate phenotype. ${ }^{12}$ The lack of reported cases in proved Hurler disease may be related to the short life span, with death occurring before the development of glaucoma; or the masking of glaucoma by severe corneal clouding; or the lack of detailed ophthalmological examination in a child severely retarded by a disease known to produce blindness of multifactorial origin.

There is increasing awareness of the clinical and therefore possible genetic heterogeneity within the individual mucopolysaccharidoses as well as the clinical similarities between the diseases themselves. Therefore earlier reports relating to the different diseases require critical evaluation, because the enzymological techniques necessary to identify them definitively were rarely available.

Evidence suggesting the possibility of a specific association between the mucopolysaccharidoses and the development of glaucoma arises from an observation of Peterson and Jocson, ${ }^{13}$ whose perfusion studies with enucleated rhesus monkey eyes showed that hyaluronidase reduces the aqueous outflow resistance. They concluded that the presence of mucopolysaccharides in the outflow apparatus is a factor influencing the normal drainage of fluid from the anterior chamber. Confirmatory studies in man have been possible only on eyes containing orbital tumours. ${ }^{14}$

Hyaluronidase breaks down glycosaminoglycans by splitting the internal glycosidic bonds between the individual sugar residues and not by sequential degradation of the polysaccharide chain, as is the case with exoglycosidases, specific deficiencies of which cause the mucopolysaccharidoses-for example, $\alpha$-iduronidase deficiency and Hurler disease. This effect of hyaluronidase on ocular drainage could be by virtue of its action on either extracellular or intracellular deposits of the glycosaminoglycans, since the enzyme could gain access to the interior of the cells by pinocytosis. The mucopolysaccharides are incompletely degraded in Hurler disease and accumulate in the extracellular fluid ${ }^{15}$ as well as in lysosomes and may in turn inhibit other degradative 
enzymes including hyaluronidase, ${ }^{16}$ and this could result in an increased resistance to aqueous outflow.

The drainage of fluid from the anterior chamber of the eye is also thought to depend on the formation of temporary vacuoles in, or vacuolar channels across, the endothelial lining of the outflow apparatus. ${ }^{14} 17$ If the cytoplasm of these endothelial cells is disrupted by stored mucopolysaccharide in the same way as the connective tissue cells which we have demonstrated, it is likely that this function will be impaired. This is another possible mechanism by which the abnormally stored mucopolysaccharides could interfere with aqueous drainage and cause glaucoma.

\section{References}

1 Hers HG. Inborn lysosomal diseases. Gastroenterology $1965 ; 48$ : 625-33.

2 Leroy J-G, Neetens A. The mucopolysaccharidoses in ophthalmology: presentation of a challenging patient. Bull Soc Belg Ophthalmol 1975; 170: 621-8.

3 Spranger J, Cantz M, Gehler J, Liebaers I, Theiss W. Mucopolysaccharidosis II (Hunter disease) with corneal opacities. Eur J Pediatr 1978; 129 : 11-16.

4 Cantz M, Kresse H, Barton RW, Neufeld E. Corrective factors for inborn errors of mucopolysaccharide metabolism. Methods Enzymol 1972; 28: 884-97.

5 Spurr AR. A low-viscosity epoxy resin embedding medium for electron microscopy. J Ultrastruct Res 1969; 26: $31-43$.

6 Kenyon KR. Ocular manifestations and pathology of systemic mucopolysaccharidoses. Birth Defects 1976; 12: 133-53.

7 Van Hoof F. Mucopolysaccharidoses. In: Hers HG, Van Hoof F, eds. Lysosomes and Storage Diseases. New York: Academic Press, 1973: chapter 8.

8 Quigley HA, Maumenee AE, Stark WJ. Acute glaucoma in systemic mucopolysaccharidosis IS. Am J Ophthalmol 1975; 80: 70-2.

9 D'Epinay SL, Remé CE. Kongenitales Glaucom bei eienem Hurley-Syndrom und einem Lowe-Syndrom. Klinische und electronmikroskopische Befunde. $A d v$ Ophthalmol 1978; 36: 80-9.

10 Van Hoof F. Mucopolysaccharidoses and mucolipidoses. In: Raine DN, ed. Molecular variants in disease. J Clin Pathol 1974; 27, Supplement 8, 1-11.

11 McKusick VA, Neufeld EF, Kelly TE. In: Stanbury JB, Wyngaarden JB, Fredrickson DS, eds. The Metabolic Basis of Inherited Disease. 4th Edition. New York: McGraw-Hill, 1978: 1288.

12 Thompson JN, Finley SC, Lorincz AE, Finley WH. In: Bergsma D, ed. Disorders of Connective Tissue. New York: National Foundation, March of Dimes, 1975: 11 (6): 341-6.

13 Peterson WS, Jocson VL. Hyaluronidase effects on aqueous outflow resistance. Am J Ophthalmol 1974; 77: 573-7.

14 Grierson I, Lee WR. Acid mucopolysaccharides in the outflow apparatus. Exp Eye Res 1975; 21 : 417-31.

15 Calatroni A, Donnelly PV, Di Ferrante N. The glycosaminoglycans of human plasma. J Clin Invest 1969; 48: 332-43.

16 Aronson NN, Davidson EA. Lysosomal hyaluronidase from rat liver. J Biol Chem 1967; 242: 441-4.

17 Tripathi RC. Mechanism of the aqueous outflow across the trabecular wall of Schlemm's canal. Exp Eye Res 1971 ; 11: 116-21.

18 McKusick VA, Kaplan D, Wise D, et al. The genetic mucopolysaccharidoses. Medicine 1965; 44: 445-83. 